\title{
Акустическая диагностика прочности оптических волокон в кабеле
}

\author{
В.А. Андреев ${ }^{1}$, А.В. Бурдин ${ }^{1,2}$, В.А. Бурдин ${ }^{1, *}$, М.В. Дашков ${ }^{1}$ \\ ${ }^{I}$ Поволжский государственный университет телекоммуникаций и информатики \\ ${ }^{2}$ Научно-производственное объединение Государственный оптический институт \\ им. С.И. Вавилова \\ *E-mail: burdin@psati.ru
}

DOI: 10.31868/RFL2020.134-135

На современном этапе развития сетей связи к наиболее актуальным проблемам относится задача прогноза срока службы оптических кабелей, введенных в эксплуатацию. Это обусловлено тем, что срок службы оптических кабелей на линиях, построенных в 90-е годы прошлого столетия превысил или близок к декларируемому производителями кабеля - 25-30 лет. Согласно принятым рекомендациям срок службы оптического кабеля оценивают сроком службы в нем оптических волокон [1]. Это обосновано, поскольку все остальные элементы конструкции оптического кабеля служат для защиты оптических волокон от внешних факторов. Для прогноза срока службы оптического волокна с заданной вероятностью используют хорошо известные формулы, согласно которым искомые оценки определяются соотношением приложенной к оптическому волокну нагрузкой и его прочностью [1, 2]. Распределения напряжений в оптических волокнах кабельной линии измеряют рефлектометрическими методами. Напряжения в оптических волокнах вследствие растягивающих нагрузок определяют по результатам измерений, проводимых с помощью BOTDR, а напряжения на изгибах оптических волокон оценивают по результатам измерений распределений изгибов оптических волокон вдоль кабельной линии в кабеле и кассетах муфт [3]. Рекомендаций по методам неразрушающего контроля прочности оптических волокон в кабеле нет.

Достаточно давно широкое распространение получили средства неразрушающего контроля изделий из различных материалов, базирующиеся на известном методе акустической эмиссии [4]. Данный метод заключается в измерении сигналов акустической эмиссии изделия, к которому прикладывается механическая нагрузка и последующем определении прочности изделия и/или локализации дефекта по характеристикам сигнала акустической эмиссии и приложенной механической нагрузки. Для измерения сигнала акустической эмиссии и контроля нагрузки устанавливают специальные датчики. Известно применение подобного решения для оценивания прочности жгутов оптических волокон [5].

В последние три десятилетия широкое распространение получили распределенные волоконно-оптические акустические датчики (DAS - Distributed Fiber Sensor), которые характеризуются устойчивостью к электромагнитным помехам, высокой чувствительностью и большой полосой пропускания $[6,7]$. Здесь высокочувствительным сенсором является оптическое волокно. Учитывая характеристики DAS, были рассмотрены возможности применения данных систем для измерения акустической эмиссии собственно оптического волокна. Предлагается метод неразрушающего контроля прочности оптического волокна в кабеле на основе метода акустической эмиссии, отличающийся от известных тем, что механическая нагрузка в оптическом волокне создается за счет виброакустического воздействия на кабель, а для измерений сигнала акустической 
эмиссии и контроля уровня воздействующего вибро-акустического сигнала в качестве акустического сенсора используется само тестируемое оптическое волокно. Условная схема для одного из вариантов реализации предлагаемого метода приведена на рис.1. Здесь 1 и 2 - тестируемое и эталонное оптические волокна, соответственно, 3 - источник вибро-акустического воздействия, 5 оптический коммутатор, 4 - измерительная система.

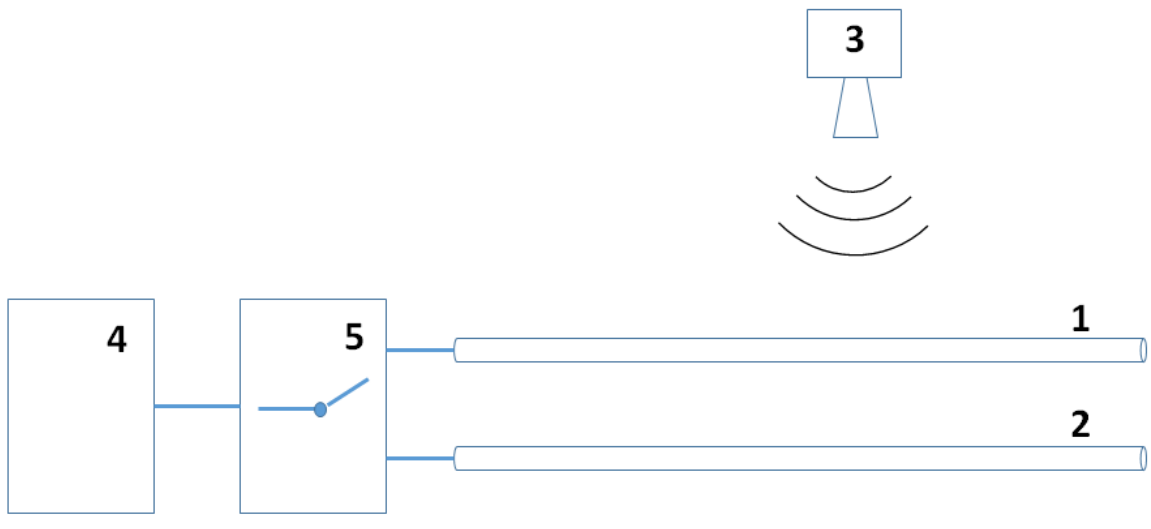

Рис.1. Схема варианта реализации предложенного способа.

В работе представлено теоретическое обоснование предлагаемого метода и результаты его экспериментальной апробации. Представлено описание эксперимента. Приведены данные измерений параметров воздействующего акустического сигнала, сигнала акустической эмиссии и полученные в результате их обработки оценки прочности оптических волокон образцов оптических кабелей, находившихся в эксплуатации с 1996, 1998, 2011 и 2017 годов, соответственно. Данные оценки были сопоставлены с оценками прочности этих же волокон, полученными в дальнейшем методом разрушающего контроля. Использовался метод двухточечного изгиба [8]. Результаты апробации демонстрируют потенциальные возможности применения предлагаемого метода.

\section{Литература}

[1] ITU-T G-series Recommendations - Supplement 59, Guidance on optical fibre and cable reliability, $21(2018)$.

[2] IEC TR 62048:2014 Optical fibres - Reliability - Power law theory, 66 (2014).

[3] I. Sankawa, Y. Koyamada et al., IEICE Transactions on Communications E76-B(4), 402-409 (1993).

[4] В.Н. Иванов, Территория NDT 1, 44-51 (2019)

[5] A. Cowking, A. Attou et al. J. Mater. Sci. 26, 1301-1310 (1991).

[6] Y. Wu, J. Gan et al., IEEE Photonics Journal 7(6), 6803810 (2015).

[7] Y. Muanenda, Hindawi Journal of Sensors 23(3897873), 1-16 (2018).

[8] ГОСТ Р МЭК 60793-1-33-2014 